\title{
MENGATASI KONSTIPASI PASIEN STROKE DENGAN MASASE ABDOMEN DAN MINUM AIR PUTIH HANGAT
}

\author{
Dameria Br Ginting ${ }^{1,2^{*}}$, Agung Waluyo ${ }^{3}$, Lestari Sukmarini ${ }^{3}$
}

1. Program Studi Ilmu Keperawatan, STIKes SUMUT, Medan 20136, Indonesia

2. Program Studi Magister, Fakultas Ilmu Keperawatan, Universitas Indonesia, Depok 16424, Indonesia

3. Fakultas Ilmu Keperawatan, Universitas Indonesia, Depok 16424, Indonesia

*E-mail: ginting_dameria@yahoo.com

\begin{abstract}
Abstrak
Perawat memiliki peranan yang penting mengatasi konstipasi pada pasien stroke selama perawatan di rumah sakit. Penelitian ini bertujuan untuk mengetahui perbedaan masase abdomen dengan masase abdomen dan minum air putih hangat pada pasien stroke yang mengalami konstipasi terhadap proses defekasi di Kota Medan. Penelitian kuasi eksperimen dengan dua kelompok intervensi dan satu kelompok kontrol menggunakan pendekatan purposive sampling dengan total empat puluh tujuh responden, masing-masing empat belas responden kelompok masase abdomen, enam belas responden kelompok masase abdomen dan minum air putih hangat, dan tujuh belas responden intervensi standar diobservasi setiap hari selama tujuh hari. Proses defekasi terhadap ketiga kelompok dilihat dari waktu terjadinya defekasi antara kelompok intervensi I dan II dengan nilai $\mathrm{p}=0,015$, dan dari frekuensi defekasi antara kelompok intervensi II dan kelompok kontrol dengan nilai $\mathrm{p}=0,000$. Hasil penelitian ini diharapkan dapat menjadi evidence based practice dalam asuhan keperawatan medikal bedah dalam memberikan intervensi keperawatan terhadap pasien stroke yang mengalami konstipasi sehingga perawatan terapi komplementer di bidang keperawatan dapat dikenal dan memberikan manfaat sebagai pencegahan dan pengobatan alami.
\end{abstract}

Kata kunci: konstipasi, masase abdomen, minum air putih hangat, proses defekasi, stroke

\begin{abstract}
Overcoming Constipation on Stroke Patient with Abdominal Massage and Drinking Warm Plain Water. Nurses had an important role to overcome constipation of stroke patient during the treatment in hospital. This study was aimed to find out the difference of abdominal massage and abdominal massage with dringking warm plain water to defecation process of stroke patient in Medan. This quasi experimental study used two intervention groups and one group as a control, this purposive sampling approach had 47 respondents, they were 14 respondents in the abdominal massage intervention group, 16 respondents in the abdominal massage with drinking warm plain water intervention group and 17 respondents in standard intervention group. Defecation process was observed everyday for seven days. Defecation process of the three groups were analyzed from the time of significant defecation between the first and the second intervention group $(p=0,015)$, and the time of significant defecation between the second intervention and control group $(p=0,00)$. The results of this study are expected to be as evidence-based practice in medical-surgical nursing care in the nursing interventions in stroke patients who experience constipation so that complementary therapies in the field of nursing care can be known and provide to be used as a preventative and natural medicine.
\end{abstract}

Keywords: constipation, abdominal massage, drinking warm plain water, defecation process, stroke

\section{Pendahuluan}

Stroke merupakan sindrom klinis akibat gangguan pembuluh darah otak biasanya timbul secara mendadak dan mengenai usia 45-80 tahun. Menurut Smeltzer dan Bare (2008), stroke merupakan ketidaknormalan fungsi sistem saraf pusat (SSP) yang disebabkan oleh gangguan kenormalan aliran darah ke otak. World Health Organization (WHO) menetapkan bahwa stroke merupakan suatu sindrom klinis dengan gejala berupa gangguan fungsi otak secara fokal atau global yang dapat menimbulkan kematian atau kelainan yang menetap lebih dari 24 jam, tanpa penyebab lain kecuali gangguan vaskular (Rasyid, \& Soertidewi, 2007). 
Prognosis stroke dapat dilihat dari enam aspek menurut Lasmudin (1999). Keenam aspek itu adalah death (kematian), disease (kesakitan), disability (kerusakan), discomfort (ketidaknyamanan), dissatisfaction (ketidakpuasan) dan destitution (kemiskinan). Keenam aspek tersebut terjadi pada fase awal stroke atau pasca stroke (Gofir, 2009). Prognosis stroke juga dipengaruhi oleh berbagai faktor dan keadaan yang terjadi terhadap penderita stroke. Tolak ukur di antaranya outcome fungsional, seperti kelemahan motorik, disabilitas, quality of life (kualitas hidup), serta mortalitas (Gofir, 2009).

Faktor prognosis yang penting dalam morbiditas dan mortalitas pasien stroke adalah komplikasi yang terjadi pascastroke. Menurut Doshi (2003, dalam Gofir, 2009), di Singapura tingkat komplikasi stroke secara keseluruhan adalah 54,3\%, komplikasi stroke pada sistem gastrointestinal adalah ulkus, perdarahan lambung, konstipasi, dehidrasi dan malnutrisi (Rasyid \& Soertidewi, 2007). Namun, menurut Navarro, et al., (2008, dalam Gofir 2009) dari 495 pasien yang mengalami komplikasi konstipasi sebesar 7,9\%.

Di Amerika Serikat hampir setiap tahunnya dilakukan survei terkait masalah konstipasi, $15 \%$ dari jumlah populasi usia dewasa mengalami konstipasi setiap tahunnya (Higgins, 2004). Survei juga dilakukan di tujuh negara pada 13.879 sampel berusia di atas 20 tahun berdasarkan wawancara dan kuisioner rerata $12,3 \%$ orang dewasa mengalami konstipasi dan wanita lebih cenderung mengalami konstipasi dari pada laki-laki dan dilaporkan $20 \%$ mengalami konstipasi adalah lanjut usia yang dirawat di rumah dan $70 \%$ mengalami gangguan konstipasi yang kronis (Wald, 2007). Suvei dilakukan kembali tahun 2010 pada 8100 sampel berusia di atas 20 tahun dari empat negara termasuk Indonesia diperoleh hasil dari wawancara 16,2\% mengalami konstipasi (Wald, 2010). Akan tetapi, $\mathrm{Su}$, et al., (2009) melaporkan pasien stroke yang mengalami masalah konstipasi 55,2\% dari 154 pasien pada serangan stroke yang pertama.

Konstipasi dapat disebabkan oleh beberapa faktor, yaitu faktor mekanis, faktor fisiologis, faktor fungsional, faktor psikologis, dan faktor farmakologis (Nanda, 2010). Faktor mekanis berkaitan dengan gangguan neurologis, pada pasien stroke disebabkan oleh penurunan beberapa fungsi neurologis. Pertama penurunan fungsi motorik yang menyebabkan terjadi imobilisasi. Gangguan mobilitas dan ketidakberdayaan (deconditioning) adalah masalah yang paling sering dialami pasien stroke (Wahjoepramono, 2005). Imobilisasi yang berkepanjangan dapat mengakibatkan komplikasi pada pasien stroke salah satunya adalah konstipasi.

Pasien stroke yang dirawat di rumah sakit sering mengalami kelemahan anggota gerak, baik sebagian maupun seluruhnya yang menyebabkan pasien imobilisasi. Imobilisasi yang berkepanjangan berpotensi terjadi komplikasi, salah satunya adalah konstipasi. Konstipasi dapat menyebabkan tekanan pada abdomen yang memicu pasien mengejan saat berdefekasi. Pada saat mengejan yang kuat terjadi respons maneuver valsava yang dapat meningkatkan tekanan intrakranial. Peningkatan tekanan intrakranial pada pasien stroke merupakan prognosis yang buruk.

Konstipasi merupakan defekasi yang tidak teratur serta terjadi pengerasan pada feses menyebabkan pasase sulit, menimbulkan nyeri, frekuensi defekasi berkurang, volume, dan retensi feses dalam rektum (Smeltzer \& Bare, 2008). Konstipasi juga diartikan sebagai perubahan dari frekuensi defekasi, volume, berat, konsistensi dan pasase dari feses tersebut (Arnaud, 2003). Usia lanjut sering mengalami masalah konstipasi karena faktor yang mendukung, seperti imobilisasi (Norton \& Harry, 1999). Frekuensi defekasi bervariasi antara satu individu dengan individu yang lain, sehingga konstipasi ditentukan berdasarkan kebiasaan pola eleminasi orang yang normal (William \& Wikins, 2000). Namun, menurut Guyton dan Hall (2008) konstipasi berarti pelannya pergerakan tinja melalui usus besar dan sering berhubungan dengan sejumlah tinja yang kering dan keras.

Refleks defekasi ditimbulkan oleh refleks intrinsik yang diperantarai oleh sistem saraf enterik setempat. Jika feses memasuki rektum, 
peregangan dinding rektum menimbulkan sinyalsinyal aferen yang menyebar melalui pleksus mienterikus untuk menimbulkan gelombang peristaltik di dalam kolon desenden, sigmoid dan rektum, serta mendorong feses ke arah anus. Sewaktu gelombang peristaltik mendekati anus, sfingter ani internus direlaksasi oleh sinyal-sinyal penghambat dari pleksus mienterikus, jika sfingter ani eksternus secara sadar, secara volunter berelaksasi dan bila terjadi pada waktu yang bersamaan akan terjadi defekasi (Guyton \& Hall, 2006).

Proses defekasi dipercepat dengan adanya peningkatan tekanan intraabdomen dan kontraksi pada otot-otot abdomen. Proses defekasi dapat dihambat oleh kontraksi volunter otot-otot sfingter eksterna dan levator ani sehingga secara bertahap dinding rektum akan rileks dan keinginan defekasi hilang (Smeltzer \& Bare, 2008).

Masase abdomen membantu untuk merangsang peristaltik usus dan memperkuat otot-otot abdomen serta membantu sistem pencernaan sehingga dapat berlangsung dengan lancar. Masase abdomen telah dibuktikan efektif mengatasi konstipasi terhadap beberapa pene-litian. Menurut Liu, et al., (2005), masase abdomen dapat meningkatkan tekanan intra-abdomen. Pada kasus-kasus neurologi masase abdomen dapat memberikan stimulus terhadap rektal dengan somato-autonomic reflex dan adanya sensasi untuk defekasi.

Mengonsumsi air putih yang hangat dalam jumlah yang cukup dapat menyebabkan pencernaan bekerja dengan kapasitas yang maksimal. Air hangat dapat bekerja dengan melembabkan feses dalam usus dan mendorongnya keluar sehingga memudahkan untuk defekasi. Memberikan pasien minum air putih hangat yang cukup merupakan intervensi keperawatan yang mandiri. Dalam penelitian ini memberikan pasien minum air putih hangat yang dimaksud adalah memberikan minum air hangat setelah dilakukan masase abdomen sebanyak $500 \mathrm{ml}$ secara rutin untuk mengatasi konstipasi.

Masase abdomen membantu untuk merangsang peristaltik usus dan memperkuat otot-otot abdomen serta membantu sistem pencernaan dapat berlangsung dengan lancar. Masase abdomen dilakukan untuk mengatasi komplikasi yang mungkin timbul akibat konstipasi. Teknik masase abdomen yang digunakan dalam penelitian ini adalah teknik Swedish massage tecnique, yaitu masase dengan penekanan yang lembut pada jaringan yang dapat memberikan perbaikan sirkulasi darah, memperbaiki sistem pencernaan, serta memberikan kenyamanan.

Berdasarkan fenomena, pemaparan latar belakang di atas, peneliti ingin mengetahui pengaruh masase abdomen dan minum air putih hangat dalam mengatasi konstipasi terhadap pasien stroke di Rumah Sakit X Medan. Tujuan dari penelitian ini adalah untuk mengetahui perbedaan masase abdomen dengan masase abdomen dan minum air putih hangat terhadap pasien stroke yang mengalami konstipasi dalam proses defekasi.

\section{Metode}

Penelitian ini merupakan penelitian kuantitatif menggunakan metode Quasi eksperiment pendekatan post test only non equivalent control group design. Pada desain ini, kelompok eksperimen dan kelompok kontrol tidak dipilih secara random (Sugiyono, 2011). Dalam penelitian ini responden sebanyak lima belas subjek. Untuk mengantisipasi drop put, dilakukan koreksi sampel menggunakan formula sederhana: n'= $\mathrm{n} /(1-\mathrm{f})$, f $(10 \%$ atau 0,1$)$ (Sastroasmoro \& Ismael, 2010). n'= 15/0,9=16,6 dibulatkan menjadi menjadi tujuh belas subjek. Kriteria inklusi pada penelitian ini adalah pasien stroke iskemi yang sesudah tujuh hari serangan stroke; tekanan darah dalam rentang (120/80-150/100) dan tidak memiliki tanda-tanda peningkatan tekanan intrakranial sebelum, selama, dan sesudah intervensi, pasien sadar dan dapat berkomunikasi, tidak mengalami penurunan fungsi memori (dengan melakukan tes memori jangka pendek dan jangka panjang), teridentifikasi mengalami konstipasi melalui constipasi scoring system, tidak sedang mengalami peradangan pada sistem gastrointestinal, sistem perkemihan, dan sistem metabolik, tidak terdapat massa pada abdomen, dan bersedia menjadi responden. 
Penelitian dibagi dalam tiga kelompok, kelompok kontrol mendapatkan intervensi yang biasa dilakukan di ruangan seperti menganjurkan makan makanan mengandung serat, memenuhi kebutuhan cairan, aktivitas dalam batas yang dapat ditoleransi dan dengan bantuan obat laksatif. Kelompok Intervensi I dilakukan satu kali dalam tujuh hari-mendapatkan terapi standar seperti kelompok kontrol sebelum sarapan pagi, responden diberikan masase abdomen dengan teknik swedish massage selama 15-20 menit Setelah enam puluh menit, responden dipersilakan sarapan pagi Kelompok Intervensi II dilakukan satu kali dalam tujuh hari mendapatkan terapi standar seperti kelompok kontrol sebelum sarapan pagi, responden diberikan masase abdomen dengan teknik swedish massage selama 15-20 menit Kemudian responden diberi tambahan minum air hangat sebanyak $500 \mathrm{ml}$. Setelah enam puluh menit, responden dipersilakan sarapan pagi.

Maka jumlah sampel dalam penelitian ini masing-masing kelompok adalah tujuh belas subjek, jumlah sampel keseluruhan adalah lima puluh satu subjek. Namun, pada saat proses pengambilan data pada Kelompok Intervensi I terdapat dua responden yang dieksklusi karena responden demam dan satu responden yang dieksklusi pada Kelompok Intervensi II karena demam pada saat perlakuan, sehingga jumlah responden sebanyak empat puluh tujuh orang pasien stroke yang mengalami konstipasi. Untuk melihat perbedaan proses defekasi antarkelompok menggunakan analisis beda lebih dari dua mean digunakan uji ANOVA atau uji F (Hastono, 2007).

\section{Hasil}

Hasil penelitian berdasarkan waktu terjadinya defekasi dan frekuensi defekasi pada kelompok intervensi I, Intervensi II, dan intervensi standar dapat dilihat pada Tabel 1 .

Pada Tabel 1 diperoleh rerata waktu terjadinya defekasi responden pada kelompok intervensi I adalah 70,43 jam (SD 30,736). Pada kelompok intervensi II rerata waktu terjadinya defekasi responden adalah 35,25 jam $(\mathrm{SD}=25,470)$. Akan tetapi, pada kelompok kontrol rerata waktu terjadinya defekasi responden adalah 60,35 jam $(\mathrm{SD}=35,375)$. Hasil estimasi interval dapat disimpulkan bahwa 95\% diyakini bahwa rerata waktu terjadinya defekasi tercepat terdapat pada kelompok intervensi II adalah 21,68-48,82 jam. Berdasarkan hasil uji statistik dapat disimpulkan bahwa ada perbedaan waktu terjadinya defekasi di antara ketiga kelompok ( $\mathrm{p}=0,015 ; \alpha=0,05)$.

Pada Tabel 2 dapat dilihat perbedaan waktu terjadinya proses defekasi antara ketiga kelompok yang bermakna adalah antara kelompok intervensi I dengan kelompok II. Hasil dapat disimpulkan bahwa ada perbedaan yang bermakna antara perlakuan masase abdomen dengan masase abdomen dan minum air putih hangat terhadap waktu terjadinya defekasi $(p=0,015 ; \alpha=0,05)$.

Pada Tabel 3 dapat dilihat perbedaan frekuensi defekasi antara ketiga kelompok yang bermakna adalah antara kelompok intervensi II dengan kelompok kontrol. Hasil dapat disimpulkan bahwa

Tabel 1. Distribusi Waktu Terjadinya Defekasi dan Frekuensi Defekasi pada Kelompok Intervensi I, Intervensi II, dan Intervensi Standar

\begin{tabular}{llllccc}
\hline Variabel & Kelompok & N & Mean & SD & 95\% CI & p \\
\hline \multirow{2}{*}{ Waktu terjadinya defekasi } & Intervensi I & 14 & 70,43 & 30,736 & $52,68-88,18$ & \\
& Intervensi II & 16 & 35,25 & 25,470 & $21,68-48,82$ & 0,015 \\
& Kontrol & 17 & 60,35 & 35,375 & $39,82-80,88$ & \\
& Intervensi I & 14 & 1,93 & 0,829 & $1,45-2,41$ & \\
Frekuensi defekasi & Intervensi II & 16 & 2,62 & 1,0255 & $2,08-3,17$ & 0,000 \\
& Kontrol & 17 & 1,29 & 0,772 & $0,90-1,69$ & \\
\hline
\end{tabular}


Tabel 2. Perbedaan Waktu Terjadinya Defekasi pada Kelompok Intervensi I, II, dan II

\begin{tabular}{lllllrl}
\hline Variabel & & & Mean & Sig & 95\% CI & p \\
\hline \multirow{2}{*}{ Intervensi I } & Intervensi II & $35,179^{*}$ & 0,016 & $5,25-65,11$ & \\
& & Kontrol & 10,076 & 1,000 & $19,44-39,59$ & \\
& & & & & \\
\multirow{2}{*}{ Waktu terjadinya defekasi } & \multirow{2}{*}{ Intervensi II } & Intervensi I & $35,179^{*}$ & 0,016 & $65,11-5,25$ & \\
& & Kontrol & 25,103 & 0,101 & $53,59-3,38$ & 0,015 \\
& \multirow{2}{*}{ Kontrol } & Intervensi I & 10,076 & 1,000 & $35,59-19,44$ & \\
& & Intervensi II & 25,103 & 0,101 & $338-53,59$ & \\
& & & & & & \\
\end{tabular}

Tabel 3. Perbedaan frekuensi defekasi pada kelompok intervensi I, II, dan II

\begin{tabular}{lllllll}
\hline Variabel & & & Mean & Sig & 95\% CI & P \\
\hline \multirow{2}{*}{ Intervensi I } & Intervensi II & 0,696 & 0,109 & $1,50-0,11$ & \\
& & Kontrol & 0,634 & 0,157 & $0,16-1,43$ & \\
& & & & & \\
\multirow{2}{*}{ Frekuensi Defekasi } & \multirow{2}{*}{ Intervensi II } & Intervensi I & 0,696 & 0,109 & $0,11-1,50$ & 0,000 \\
& & Kontrol & $1,331^{*}$ & 0,000 & $0,57-2,10$ & \\
& & & & & \\
& \multirow{2}{*}{ Kontrol } & Intervensi I & 0,634 & 0,157 & $1,43-0,16$ & \\
& & Intervensi II & $1,331^{*}$ & 0,000 & $2,10-0,57$ & \\
& & & & &
\end{tabular}

ada perbedaan yang bermakna antara perlakuan masase abdomen dan minum air putih hangat dengan intervensi yang standar terhadap frekuensi defekasi $(p=0,000 ; \alpha=0,05)$.

\section{Pembahasan}

Minum air hangat dapat memberikan sensasi yang cepat menyebarkan gelombang panasnya ke segala penjuru tubuh manusia. Pada saat yang bersamaan pembuluh darah akan berdilatasi sehingga dapat mengeluarkan keringat dan gas dalam tubuh. Abdomen salah satu organ yang memiliki reseptor terhadap suhu yang panas dan lebih dapat mendeteksi suhu panas dibanding dengan suhu dingin (Guyton \& Hall, 2006).

Hasil penelitian menunjukkan waktu terjadinya defekasi pada kelompok masase abdomen lebih lambat, yaitu rerata waktu terjadinya defekasi adalah 70,43 jam jika dibandingkan dengan kelompok kontrol, yaitu rerata waktu terjadi defekasi responden adalah 60,35 jam yang hanya mendapatkan intervensi yang standar. Salah satu faktor yang dapat menyebabkan perbedaan tersebut adalah dilihat dari hasil penelitian bahwa responden yang mendapatkan masase abdomen mayoritas berada pada tingkat kemandirian rendah dan ketergantungan total. Responden pada kelompok masase abdomen ini secara fisik mengalami penurunan kekuatan otot dan kelemahan pada otot-otot abdomen yang memicu perlambatan waktu yang dibutuhkan feses untuk berpindah dari kolon ke rektum, dibandingkan dengan responden pada kelompok kontrol ratarata memiliki tingkat kemandirian yang sedang. Dalam beberapa aktivitas responden pada kelompok kontrol masih dapat melakukan pergerakan secara aktif, pergerakan secara aktif dapat memengaruhi percepatan waktu perpindahan feses dari kolon ke rektum.

Hasil penelitian ini telah membuktikan bahwa telah dapat mengatasi masalah konstipasi pada pasien stroke setelah masase abdomen dilakukan setiap hari selama tujuh hari. Masase abdomen efektif mengatasi konstipasi jika dilakukan secara rutin setiap hari. Hal ini yang menyebabkan perbedaan dengan penelitian terdahulu karena pada penelitian terdahulu masase abdomen tidak dilakukan setiap hari secara rutin. Masase abdomen yang dilakukan secara rutin dapat 
merangsang peristaltik usus serta memperkuat otot-otot abdomen yang akan membantu system pencernaan dapat berlangsung secara lancar (Folden, 2009).

Berdasarkan hasil penelitian dapat diketahui bahwa frekuensi defekasi antara kelompok responden yang mendapat masase abdomen dengan kelompok kontrol tidak berbeda jauh. Hal ini disebabkan oleh pengaruh jumlah serat yang dikonsumsi oleh kelompok kontrol lebih banyak dibandingkan dengan kelompok masase abdomen. Responden yang menjadi kelompok kontrol adalah responden yang berasal dari rumah sakit swasta yang setiap penyajian menu makan siang selalu disertai dengan buah-buahan, dibandingkan dengan responden kelompok masase abdomen yang berasal dari rumah sakit pemerintah. Hal ini dapat menjadi salah satu faktor yang menyebabkan perbedaan frekuensi defekasi kelompok masase abdomen dengan kelompok intervensi standar tidak berbeda jauh.

Frekuensi defekasi pada responden yang mendapat masase abdomen dibandingkan dengan frekuensi defekasi pada responden kelompok masase abdomen dan minum air putih hangat lebih sedikit. Perbedaan frekuensi ini dapat dipengaruhi oleh jumlah asupan cairan resonden terhadap kelompok masase abdomen setiap harinya, kemungkinan lebih sedikit dibandingkan dengan kelompok masase abdomen yang diberi tambahan minum air putih hangat $500 \mathrm{ml}$ setiap hari. Jika asupan cairan dalam tubuh kurang, tubuh akan menyerap cadangan air dalam usus dan absorbsi air menjadi lebih sedikit menyebabkan kandungan air dalam feses akan diserap kembali. Kekurangan kandungan air dalam feses menyebabkan feses menjadi kering, keras, dan membutuhkan waktu yang cukup lama dari kolon transfersum sampai ke kolon sigmoid.

Hasil penelitian yang sudah dilakukan dan hasil penelitian terdahulu dapat disimpulkan bahwa masase abdomen efektif dilakukan untuk mengatasi konstipasi pada pasien stroke. Namun, memerlukan intervensi tambahan agar efek terhadap waktu terjadinya defekasi lebih cepat sehingga frekuensi defekasi juga dapat bertambah.

Pada penelitian ini, minum air hangat sebanyak $500 \mathrm{ml}$ diberikan setelah responden mendapatkan masase abdomen. Beberapa responden awalnya tidak dapat meminum air hangat yang telah disediakan $500 \mathrm{ml}$ sekaligus sehingga pada awalnya harus diberikan secara bertahap untuk mengurangi ketidaknyamanan.

Pada kelompok yang mendapatkan masase abdomen dan minum air putih hangat, waktu terjadinya defekasi dimulai dalam dua puluh empat jam terhadap perlakuan di hari pertama. Dilihat dari waktu terjadinya proses defekasi pada kelompok ini lebih cepat, yaitu rata-rata waktu terjadi defekasi responden adalah 35,25 jam dibandingkan dengan kelompok yang hanya mendapat masase abdomen. Masase abdomen dan mendapatkan minum air putih hangat sebanyak $500 \mathrm{ml}$ setelah dilakukan masase abdomen terbukti dapat mempercepat terjadinya proses defekasi. Proses defekasi ini dapat berlangsung secara cepat disebabkan oleh stimulasi pada otot-otot abdomen yang secara langsung dapat merangsang peristaltik usus ditambah dengan minum air hangat sebanyak $500 \mathrm{ml}$ yang akan memberikan suasana yang encer dan cair pada usus. Suasana yang encer ini akan memudahkan usus halus mendorong sisa makanan untuk diabsorbsi di usus besar. Pernyataan ini didukung oleh teori yang menyatakan bahwa pemberian minum air putih hangat memberikan efek hidrostatik dan hidrodinamik dan hangatnya membuat sirkulasi peredaran darah khususnya pada daerah abdomen menjadi lancar. Secara fisiologis, air hangat juga memberi pengaruh oksigenisasi dalam jaringan tubuh (Hamidin, 2012). Hal serupa diungkapkan oleh Yuanita (2011), minum air hangat dapat memperlancar proses pencernaan, karena pencernaan membutuhkan suasana yang encer dan cair. Pada penderita konstipasi minum air hangat sangat tepat untuk membantu memperlancar pencernaan karena dengan minum air hangat partikel-partikel dalam usus akan dipecah dan menyebabkan sirkulasi pencernaan menjadi lancar sehingga mendorong usus mengeluarkan feses. 
Frekuensi defekasi responden pada kelompok masase abdomen dan minum air putih hangat lebih sering dua kali (2,62 kali) dibandingkan dengan kelompok yang mendapat masase abdomen frekuensi defekasi satu kali (1,93 kali), sementara itu frekuensi defekasi pada kelompok kontrol adalah 1,29 kali. Namun, jika dilihat dari hasil penelitian terdahulu yang dilakukan oleh Tampubolon (2008), frekuensi defekasi pada kelompok intervensi empat kali lebih sering dibandingkan dengan kelompok kontrol. Hal ini dapat disebabkan oleh perbedaan jumlah air minum yang diberikan kepada responden yang mengalami konstipasi. Jika pada penelitian ini responden diberikan minum air putih hangat sebanyak $500 \mathrm{ml}$ sementara penelitian oleh Tampubolon (2008), memberi minum air putih sebanyak $1500 \mathrm{ml}$. Jadi, dapat disimpulkan bahwa semakin banyak asupan cairan yang diminum maka proses defekasi akan lebih baik.

Proses defekasi pada kelompok yang hanya mendapatkan intervensi standar dimulai pada hari kedua. Proses defekasi pada kelompok ini hanya memperoleh terapi standar dari rumah sakit berupa anjuran makan makanan yang mengandung serat, memenuhi kebutuhan cairan, melakukan aktivitas dalam batas yang dapat ditoleransi, dan memberikan obat laksatif membantu melunakkan feses. Intervensi standar yang diberikan kepada pasien yang mengalami konstipasi didukung oleh pemenuhan kebutuhan cairan dan jumlah serat yang dimakan dapat membantu terjadinya proses defekasi. Hasil penelitian ini didukung oleh teori yang dikemukakan oleh Mckay (2012), dengan diet kaya serat sangat membantu untuk memperlancar pencernaan sehingga dapat mencegah konstipasi, namun pada pasien yang mengalami dehidrasi asupan cairan harus ditambah dengan minum lebih banyak.

Frekuensi defekasi pada kelompok yang hanya mendapatkan intervensi standar ini jauh lebih sedikit bahkan ada yang sama sekali belum terjadi proses defekasi selama observasi dilakukan dibanding kelompok intervensi masase abdomen dan kelompok masase abdomen dengan mendapatkan minum air putih hangat. Hal ini disebabkan oleh banyak faktor, seperti imobilisasi, yaitu tirah baring yang lama dapat memengaruhi penurunan tonus otot abdomen, motilitas, serta tonus usus sehingga menyebabkan waktu terjadi defekasi menjadi lambat. Hal ini disebabkan oleh kurangnya latihan pergerakan yang dilakukan, baik secara aktif oleh pasien maupun secara pasif oleh keluarga dan tenaga kesehatan. Menurut Smeltzer dan Bare (2008), tirah baring yang lama merupakan penyebab terjadinya konstipasi pada pasien stroke.

Tidak dapat diabaikan secara psikologis seseorang yang lama dirawat dengan diagnosis stroke dapat mengakibatkan seseorang menjadi depresi, emosi yang tidak stabil, rasa cemas, takut, dan merasa rendah diri. Menurut Guyton dan Hall (2006), seseorang yang dalam keadaan cemas, depresi, stres dan gangguan mental lainnya memengaruhi kerja hormon pencernaan (sekretin, gastrin, kolestositokinin) yang mengakibatkan penurunan nafsu makan, menurunkan motilitas usus dan mekanisme tubuh meningkatkan rangsangan saraf simpatis yang menghambat pengosongan lambung, sehingga menyebabkan seseorang dalam keadaan ini mengalami konstipasi. Dalam penelitian ini, faktor psikologis tersebut tidak dikaji sebagai faktor yang dapat memengaruhi terjadinya konstipasi pada pasien stroke.

\section{Kesimpulan}

Terdapat perbedaan waktu terjadinya proses defekasi yang signifikan antara kelompok intervensi I dengan kelompok II, bahwa ada perbedaan yang bermakna antara perlakuan masase abdomen dengan masase abdomen dan minum air putih hangat terhadap waktu terjadinya defekasi $(p=0,015 ; \alpha=0,05)$. Terdapat perbedaan frekuensi defekasi yang signifikan antara ketiga kelompok, yaitu antara kelompok intervensi II dan kelompok kontrol, bahwa ada perbedaan yang bermakna antara perlakuan masase abdomen dan minum air putih hangat dengan intervensi yang standar terhadap frekuensi defekasi $(\mathrm{p}=$ $0,000 ; \alpha=0,05)$.

Bagi keilmuan keperawatan, hasil penelitian ini diharapkan dapat sebagai evidence based 
practice dalam asuhan keperawatan medikal bedah dalam memberikan intervensi keperawatan pada pasien stroke yang mengalami konstipasi sehingga perawatan terapi komplementer di bidang keperawatan dapat dikenal dan memberikan manfaat untuk digunakan sebagai pencegahan dan pengobatan alami. Bagi peneliti selanjutnya dapat digunakan sebagai data dasar untuk melakukan penelitian selanjutnya dengan membandingkan masase abdomen dan minum air putih hangat dengan tindakan kompres hangat (range of motion) pada daerah perut untuk melihat proses defekasi yang lebih efektif (YS, $\mathrm{KN}, \mathrm{EF})$.

\section{Referensi}

Arnaud, M.J. (2003). Mild dehydration: A risk factor of constipation? European Journal of Clinical Nutrition, 57 (2), 588-595.

Gofir, A. (2009). Manajemen stroke: Evidence based medicine. Yogyakarta: Pustaka Cendikia Press.

Guyton, A.C., \& Hall, J.E. (2006). Buku ajar fisiologi kedokteran (edisi 9) (Irawati Setiawan, penerjemah). Jakarta: EGC.

Hamidin, A. (2012). Keampuhan terapi air putih: Untuk penyembuhan, diet, kehamilan dan kecantikan. Yogyakarta: Media Presindo.

Higgins, P.D., \& Johanson, J.F. (2004). Epidemiology of constipation in North America: A systematic review. The American Journal of Gastroenterology, 99, 750-759.

Liu, Sakakibara., T. Odaka., T. Uchiyama., T. Yamamoto., T. Ito., T. Hattori (2005). Mechanism of abdominal massage for difficult defecation in patient with myeolopathy. Journal of Neurology, 252, 1280-1282.

Mckay, S.L., Fravel, M., \& Scanlon, C. (2012). Evidence-based practice guildeline: management of constipation. Gerontology nursing, 38 (7), 9-15. Journal of Gerontological Nursing. Diperoleh dari http://www.healio.com/nursing/journals/jg $\mathrm{n} / 2012-7-38-7 / \% 7 \mathrm{Bf} 9178 \mathrm{bcd}-5 \mathrm{~d} 38-4 \mathrm{ad} 2-$ 92ea-25be9eee4a1b\%7D/management-ofconstipation

Folden, S.L. (2002). Practice guidelines for the management of constipation in adults. Rehabilitation nursing, 27 (5), 169-175. Diperoleh dari http://www.rehabnurse.org/pdf/BowelGuidef orWEB.pdf

Norton, C. (1999). Ivestigation and treatment of bowel problem. Medical post, 21 (1), $27-$ 36. Nursing \& Allied Health Source

Rasyid, A., \& Soertidewi, L. (2007). Unit stroke: Manajemen stroke secara komprehensif. Jakarta: Bala Penerbit Fakultas Kedokteran Indonesia.

Smeltzer, S.C., \& Bare, B.G. (2008). Brunner \& Suddarth: Textbook of medical surgical nursing. Philadelphia: Lippincott Williams \& Wilkins.

Su, Y., Zhang, X., Zeng, J., Pei, Z., Cheung, R.T.F., Zhou, Q., Ling, L., Yu, J., Tan, J., $\&$ Zhang, Z. (2009). New-onset constipation at acute stage after first stroke: Incidence, risk factors, and impact on the stroke outcome. Stroke, 40, 1304-1309.

Sugiyono. (2009). Statistika untuk penelitian (cetakan ke-14). Bandung: Alfabeta.

Tampubolon, L. (2008). Pengaruh terapi air putih pada pasien konstipasi terhadap proses defekasi (Tesis, tidak dipublikasikan). FIK UI, Depok - Jawa Barat.

Tappan, F. \& Benjamin, P. (1998). Healing massage techniques: Classic, holistic, and emerging methods (3rd Ed.). USA: AppletonLange.

Wald, A. (2006). Constipation in the primary care setting: current concepts and misconceptions. The American journal of medicine, 119, 227-236.

Yuanita, A. (2011). Terapi air putih. Jakarta: Klik Publishing. 